\title{
Israeli Violations of Agricultural Land in the Gaza Strip 1948-2019: A Study in urban Planning and Land use
}

\author{
Dr. Fawzy Saeed Al-Jadba, Dr Ra'ed A. Salha \\ Islamic University, \\ Jamal Abdel Nasser Str,Unrwa, \\ Gaza, Palestine
}

\begin{abstract}
The Israeli occupation of Palestine in 1948 is considered one of the most dangerous occupations in history. Since the establishment of the Israeli occupation state, it has systematically carried out different kinds of attacks and violations of the Palestinians' lands in general, and the land of peasants in the Gaza Strip in particular. This study sheds light on the Israeli attacks targeting the agricultural land in the Gaza Strip between the years 1948-2012. First, it discusses the geographical features of the Gaza Strip, and then it historically traces the Israeli attacks against the lands of the Palestinians in the Strip from 1948 to 2019. Third, the study describes the methods used by Israel in carrying out its violations of agricultural lands. The study also discusses the challenges facing Palestinian farmers, particularly razing their lands by Israeli army bulldozers in addition to the problem of water shortage and salinity. The study further details the Israeli strategies to destroy the agricultural sector in the Gaza Strip, the results of Israeli violations on agricultural lands, and the obstacles facing farmers due to these attacks. The study concludes that the Israeli attacks have resulted in impeding the growth of the agricultural sector and that Israel has put in place several policies to seize control of the agricultural lands in the Gaza Strip. The study recommends developing agricultural policies to reflect Palestinian needs and priorities, pay due attention to livestock production, and develop the transport, water and electricity infrastructure so as to improve agricultural production in the Gaza Strip.
\end{abstract}

Key words - Agricultural sector, the Geographical features, Urban Planning, Agricultural Rights.

\section{INTRODUCTION}

Highlight Since its establishment in 1948, the Israeli occupation state has systematically carried out various kinds of aggressions and violations of the Palestinians' lands in general, and the land of peasants in the Gaza Strip in particular. These violations are part of an overall Israeli strategy aiming at consolidating Jewish Zionist presence in as much of historic Palestine as possible and to leave the Palestinian people on as little of the land. Israel is primarily a colonial state built on Palestinian land and imposed by military force in violation of numerous United Nations resolutions. Hence the existence of the Zionist state has required adopting all kinds of oppressive practices and violations to buttress its occupation.

Violating the rights of the Palestinian farmers is obviously one of the pillars of the ongoing military occupation. These violations have been a main cause of pain and suffering for Palestinian farmers. Therefore, it is of crucial importance that we address this problem and show the facts and realities relating to the Palestinian rights generally and the Palestinian farmers particularly. Numerous United Nations resolutions along with human rights reports and nongovernmental organizations amply criticized the illegal Israeli practices toward the rights and property of the Palestinians in general including the farmers in the Gaza Strip.

Therefore, the present study highlights the significance of one of the most serious issues in the ZionistPalestinian conflict, which has recently been heightened during the last military offensives on Gaza, from geographical and human rights viewpoints. It aims to expose the Israeli policies targeting the rights of the Palestinian farmers and highlight the impact of such policies on the agricultural sector in the Gaza Strip.

\section{METHODOLOGY}

The study aimed to answer the following questions:

1. What are the Israeli violations of the Palestinian farmers' rights in the Gaza Strip between 1948 and 2019 ?

2. To what extent have the Israeli attacks on Palestinian farmers affected the agricultural sector in the Gaza Strip?

To answer the study questions, the researcher used a historical approach to trace the escalation of the Israeli violations against the Palestinian farmers in the Gaza Strip. Next, he adopted a descriptive approach to show the results of these ongoing violations and finally he took an objective approach to explain the Israeli measures actions against the Palestinians farmers.

\section{THE GEOGRAPHICAL FEATURES OF THE GAZA STRIP}

1) The Gaza Strip is an enclave territory of the Occupied Palestinian Territories. It was named so as a military term, and not as a distinct geographical province, after signing the Egyptian-Israeli armistice agreement in 1949 following the 1948 War. It is part of the Palestinian coastal plain characterized by its topography and climate (1). 
2) The rectangular-shape strip is about $45 \mathrm{~km}$ long that extends from the north to the south, and between $6-12 \mathrm{~km}$ wide from east to west, with an area of $360 \mathrm{~km}^{2}$. It is located on the eastern coast of the Mediterranean Sea that borders Egypt from the southwest, and the Occupied Palestinian Territories of 1948 on the east and north. This has given the Gaza Strip an important geographical location throughout the ages.

3) The Strip's terrain is generally flat, about 20-40 meters above sea level. In some locations, it reaches 85 meters at Tal Al-Muntar area to the east of Gaza City and about 70 meters near Beit Hanoun in the north. Gaza Valley dissects the Strip from the south of Gaza City. This is also important in that this belt is one of the major areas for supplying the aquifers with nearly $60 \%$ of Gaza's underground water.

The Gaza Strip has a Mediterranean climate, although it is affected by semi-desert climate prevailing in the north of the Sinai Peninsula, and it is generally characterized by moderate climate as the average annual temperature is $20^{\circ} \mathrm{C}$, and the amount of rainfall reaches a rate of $374 \mathrm{~mm}$. The population centres in the Strip include four major cities, two of which are ancient cities, namely Gaza and Rafah, and the other two were established and evolved in the middle Ages after the Islamic conquest, namely Deir al-Balah and Khan Younis. There are a number of villages scattered from the north to the south as follows: Beit Hanoun, Beit Lahia, Jebalia, Al-nazleh, Alzawaydah, Alqararh, Bani Suhaila, Abasan Al-Kubra, Abasan Alsughra and Khuza'a. After 1948, Palestinian refugees poured into the Gaza Strip, and therefore several refugee camps were built including Jebalia Camp, Shati Camp, Nuseirat Camp, Albureij Camp, Al-Maghazi Camp, Deir Al-Balah Camp, Khan Younis Camp and Rafah Camp

IV. According to the Palestinian Central Bureau of Statistics issued report in 2009, the Gaza Strip is home to a population of more than 1.487 .816 people, $20 \%$ inhabitants are peasants dwelling in rural areas and $80 \%$ of the population lives in the camps and cities.

\section{THE HISTORY OF THE ISRAELI VIOLATIONS AGAINST THE PALESTINIAN FARMERS IN THE GAZA STRIP}

Israeli violations have continued against the rights of the Palestinian farmers in the Gaza Strip since the establishment of the Israeli occupation state in 1948.

Israeli Violations against Farmers after the Armistice Agreement in 1949. The violations first started in the text of the Armistice Agreement which stated that the armistice line extends from the mouth of Al-Hessi Valley northeast Gaza Strip, and moving eastward through the village of Deir Snead, then crosses through Gaza-Ashkelon road to a point just 3 kilometers east of the road, and then in a direction parallel to the Gaza-Ashkelon road up to the Egyptian border in the south (2). This agreement gave the Gaza Strip $555 \mathrm{~km} 2$. Map (1) shows the real boundary line according to the coordinates stated in the Agreement, but now the Strip only extends over an area of $365 \mathrm{~km} 2$. This means taking out about $200 \mathrm{~km} 2$ of the Strip's original area, which marked the first violation of the rights of Palestinian peasants, as this area constituted farms owned by Palestinian citizens.

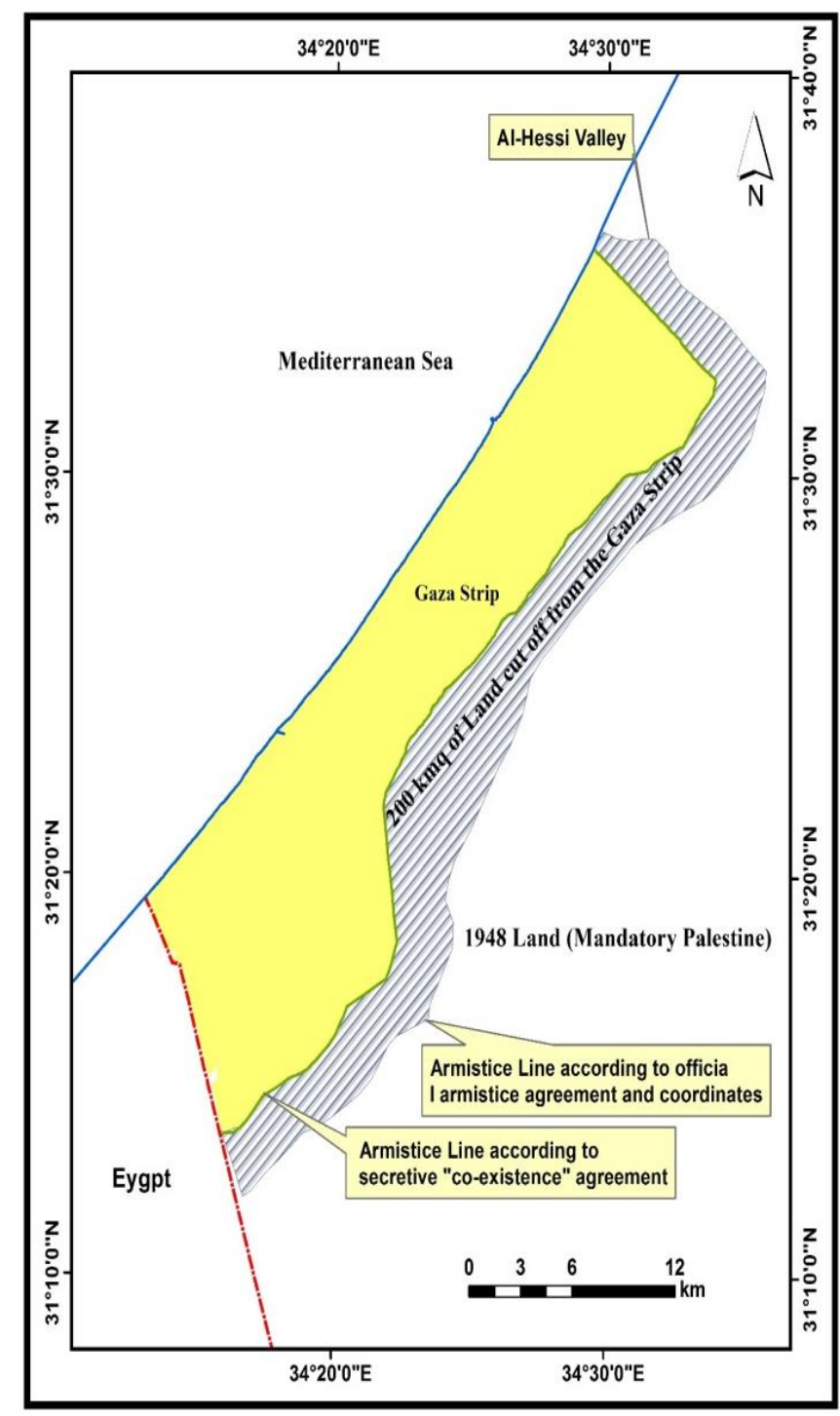

Map (1) the land theft of an area of $200 \mathrm{~km}^{2}$ following the 1949 armistice line

Source: Authors, Feb.2019

\subsection{Israeli Violations After the 1967 War}

Israel seized the fertile agricultural lands by constructing Israeli settlements inside the Gaza Strip, including 18 Jewish settlements distributed in two major zones (3):

The western zone: it has two major blocs of settlements, the northern bloc: the settlements of Elei Sinai, Nitsanit and Dugit; the southern bloc of Gush Katif settlements group which includes Netzer Hazani, Yakal, Katif, Ganei Tal, Neveh Dekalim, Gadid, Gan Orr, Bdoulih, Bneih Atzmona, Bat Sidi, Rafiah Yam and Kfar Yam. The settlement of Netzarim was located in the centre to the south of Gaza City. Map (2) describes the locations of settlements in the Gaza Strip. 
Map (2) Israeli Colonies in the Gaza Strip Source Alzaytouna Centre

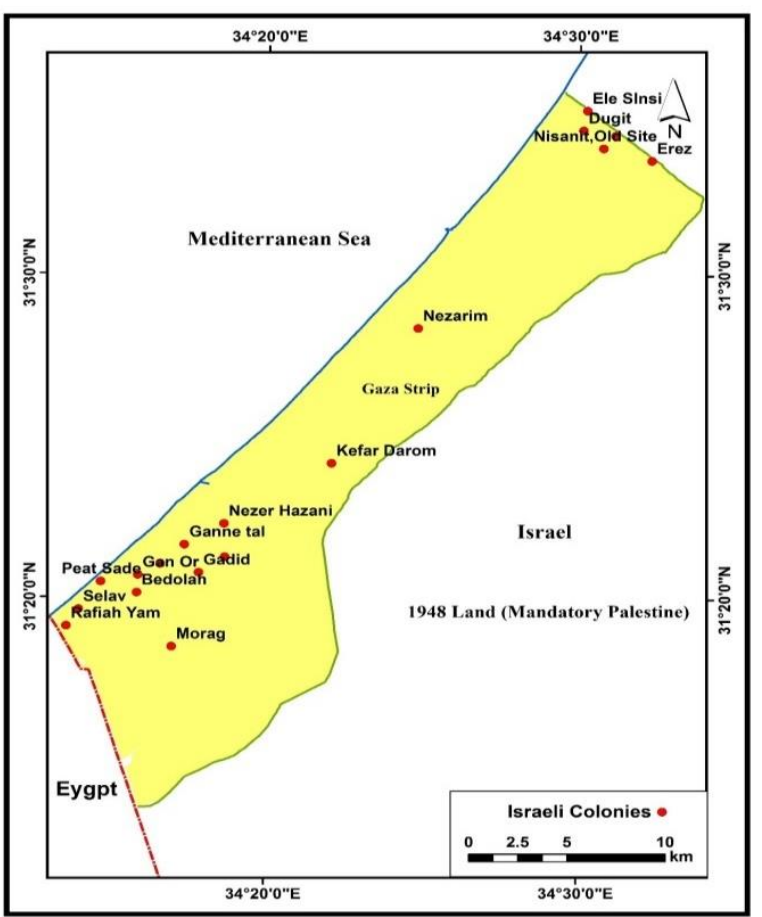

Source: Authors, Feb.2019

Map (3) Study Area - Gaza Strip Governorates $2 o 14$.

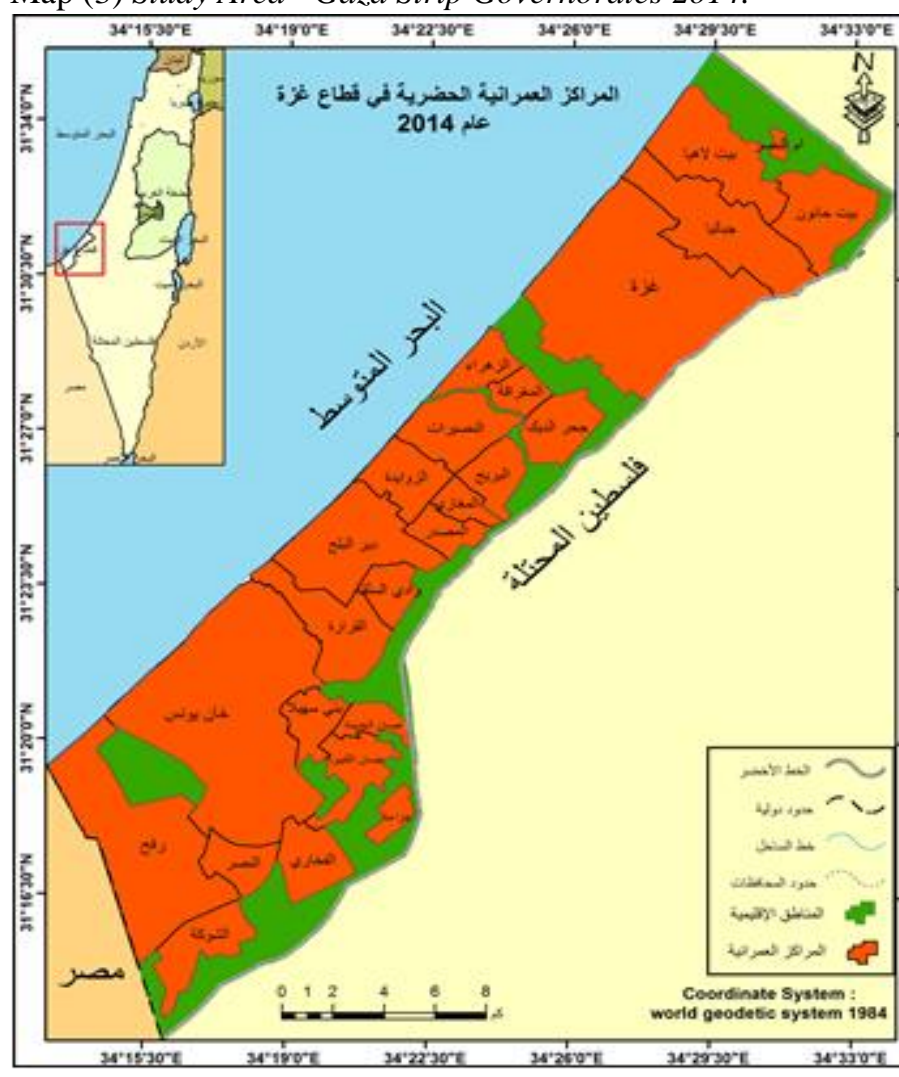

Source: Prepared by the researchers supported with (ArcGis 10.1) based on the 2015 Local Control data.

The middle zone includes Kfar Darom Colonies.
It is worth mentioning that the distribution of the Israeli settlements enabled Israel to:

1. Take full control of the Gaza Strip beach through the western settlements belt that resulted in depriving farmers of using the western road along the shore.

2. Have control over the Salah al-Din Road, the main highway (Road No. 4) that connects the north and south of the Strip spanning the entire length of the territory from Rafah rom south to Erez in the north. Israel used of matrix of roads resulting from the presence of the settlements to fragment the Gaza Strip into four parts: the northern Gaza Strip, Deir al-Balah, Khan Younis and Rafah. This was done, for example, during Al-Aqsa Intifada when it deprived the Palestinians from movement, social interaction and exporting their agricultural products.

\subsection{Contaminating Groundwater and Drinking Water by} Establishing Wastewater Collection Station

1The station was established in 1979 by an Israeli military decision after the full Israeli military occupation of the Gaza Strip in 1967 (4). The decision delimited the area on which the station would be built over the best aquifer which constitutes the main source of usable groundwater in the region. Furthermore, the steady increase of wastewater that reached it caused serious environmental effects and health problems.

2 The wastewater collection station in Beit Lahia has become the main problem facing Palestinians in the northern Gaza over the past years due to its location adjacent to large residential communities. It is about one and a half kilometers from Beit Lahia city center and the outskirts of the city up to a distance of only fifty meters away from the wastewater complex, while separating the complex from the village of Um al-Nasser sand berms only five meters away. Indeed, these flagrant violations have caused serious pollution of drinking and farming water.

\section{4.4 TYPES OF THE ISRAELI SETTLEMENTS}

There are four main types of settlements, corresponding to the general purpose of the Israeli colonization (5):

Civil settlements: they are used for living accommodations whose population work in the Israeli cities near to the Gaza Strip and the civil administration departments. Such settlements are based on an ideological, religious basis and are ranked first militarily and politically and protected by Israeli army forces.

Agrarian settlements: These are built on prime agricultural land confiscated from Palestinians and on key natural resources and are intended to seize as much governmental land as possible. The main agricultural products of these settlements are tomatoes, cucumbers and flowers that are exported to Europe and all over the world bearing the brand (Carmel). There were seven agricultural settlements in the Gaza Strip geographically distributed in a way to respond to the general purposes of Israeli colonization in Palestine. They are: Eli Sinai, Beit Sidai, Beldoh, Qatif, Jani Tal, Gadid, and Jan Orr. 
1. Industrial settlements: They are established basically near the Palestinian residential communities to keep the dangers of environmental pollution away from the Israelis. They include two big settlements, Yakal in the south and Erez in the north. Moreover, they were used for exploiting the cheap labors near the agricultural communities such as Yakal in Gush Katif in the southern Gaza strip.

2. Kibbutzim (Agrarian collective settlements): They include Morag, Netsarim and Bani Atsmona. In addition to their other aims as having military bases and special units and Israeli intelligence sites, their agricultural products are shared among their settler population.

From the above, we can conclude the following:

- The yellow regions and settlements under the Israeli control are areas of 60,072 donums.

- About $16.6 \%$ of areas in the Gaza Strip are under Israeli control.

- The number of Israeli settlers in the Gaza Strip is less than $0.6 \%$ of the Strip's total population.

- Israeli settlements were built on Palestinian governmental lands and private property.

\section{-Israeli Violations of the Rights of the Palestinian} Farmers during Al-Aqsa Intifada

- On 28 September 2000, the first spark of the AlAqsa Intifada was ignited. Shortly afterwards, Israel started using its power to demolish Palestinian homes and to raze the agricultural lands and economic facilities. Followed by laying siege to the Palestinian territories, the Palestinians have suffered from heavy losses in both lives and economy (6). Table (4) below describes the agricultural losses that Palestinians have suffered during Al-Aqsa Intifada over the period from 28/9/2000 until 26/12/2008.

Table 4: The agricultural losses over the period from $28 / 9 / 2000$ to $26 / 12 / 2008$

\begin{tabular}{|r|r|c|c|}
\hline No. & \multicolumn{1}{|c|}{ Tree Type } & Uprooted Trees No. & $\begin{array}{c}\text { Area / } \\
\text { donum }\end{array}$ \\
\hline 1 & olive & 125408 & 5701 \\
\hline 2 & palm & 79809 & 5322 \\
\hline 3 & citrus & 1375726 & 34393 \\
\hline 4 & almond & 190432 & 5771 \\
\hline 5 & grapes & 25981 & 1083,3 \\
\hline 6 & fruits & 320419 & 2124 \\
\hline 7 & forest trees & 11941 & 272,4 \\
\hline & Total & 2129716 & 54666,7 \\
\hline
\end{tabular}

- $\quad$ Source: Ministry of Agriculture 2008.

- Table 4 shows the total number of the uprooted trees in the Palestinian territories which about 2129716 trees including $5.9 \%$ olive, $3.7 \%$ palm trees, $65 \%$ citrus, $9 \%$ almond, $1.2 \%$ grapes and $15 \%$ fruits and $0.6 \%$ forest trees. From the above it is clear that there is a fierce war on citrus, which is the only competitor to Israel's citrus production (7).
- Table 1 also describes the total number of the razed area which reaches 54666.7 donums, including $63 \%$ citrus, and more than $10 \%$ olive. The number of uprooted and razed olive trees and citrus are apparently high because they are perennial trees.

- The Palestinian farmers still face the ongoing Israeli violations and destruction in all aspects of their life (8). For instance, Israel destroyed or razed 3799 donums of greenhouses, 37484 donums of lands planted with vegetables, 11440 donums of field crops, 1429 agricultural warehouses, an area of 152582 square meters of poultry farms, 90540 animal pens, killing about 4984 sheeps and 1385 cows. In addition, Israel destroyed 31947 beehives, 782 water wells, 113660 donums of irrigation systems and 2022707 linear meters of fence. Finally, about 18219 Palestinian farmers have been affected by Israeli violations. These violations and destructions have an estimated total cost of US\$ 496,727,874 (see Table 5).

Table 5: violations and destructions

\begin{tabular}{|c|c|c|}
\hline Loss Type & Unit & Total \\
\hline Destruction of Agricultural Stores & No. & 1429 \\
\hline Destruction of Poultry Farms & Sq. $\mathrm{m}$ & 152582 \\
\hline Destruction of Animal pens & Sq. $\mathrm{m}$ & 90540 \\
\hline Death of Sheep and goats & No. & 4984 \\
\hline Death of Cows and Cattle & No. & 1385 \\
\hline Destruction of Beehives & No. & 31947 \\
\hline Destruction of Water Wells & No. & 782 \\
\hline Killing Meat Poultry & No. & 488211 \\
\hline Killing Egg Poultry & No. & 258252 \\
\hline Killing Rabbits Farms & No. & 8951 \\
\hline Razing Irrigation systems & Acre & 113680 \\
\hline $\begin{array}{c}\text { Water Tanks \& Pools } \\
\text { Razing }\end{array}$ & No. & 9405 \\
\hline Razing Fences & Meter & 202277 \\
\hline Razing Water Pipes & Meter & 2264717 \\
\hline Number of Farmers & No. & 18219 \\
\hline
\end{tabular}

Source: Ministry of Agriculture 2009.

\section{Israeli Violations against the Palestinian Farmers after 2008}

Israel waged a brutal war on the Gaza Strip on 27 December 2008 and continued until 18 January 2009. The military offensive was not only targeting civilians and destroying the infrastructure of the Gaza Strip, but also depriving the Palestinians from the fundamental to be human rights to cope with their daily life. Consequently, the Gaza Strip requires tens of years to reconstruct after the destruction and devastation caused by the Israeli oppression.

Reports issued after that war indicated that $57 \mathrm{~km} 2$ square kilometers - the equivalent of $29 \%$ of total agricultural land in the Strip which is 196 square kilometers - were destroyed as a result of the intensive Israeli aerial bombardments and tanks and bulldozers (see Map 3). This destruction of agricultural lands by the Israeli occupation forces constitutes a flagrant, unjustified violation of International Humanitarian Law principles. Israel's breaches can only be explained in the context of what could be called Israel's premeditated intention to 
paralyze and destroy the Gaza Strip and the elimination of the population by force, starvation in a stark violation of the most basic human rights of the Palestinians in the Gaza Strip. Which in turn is part of the systematic of the Gaza Strip Israeli war? The following Map (3) describes the agricultural areas in the Gaza Strip including a Table that classifies the destroyed agricultural lands.

Table 3: classification of the destroyed agricultural lands.

\begin{tabular}{|c|c|c|}
\hline \multirow{2}{*}{ Demolished agricultural lands } & acre & percentage \\
\hline Arable lands & 31791 & $56 \%$ \\
\hline Various corps & 6891 & $12 \%$ \\
\hline Trees & 16726 & $29 \%$ \\
\hline Greenhouses & 1557 & $3 \%$ \\
\hline Total & 56966 & $100 \%$ \\
\hline
\end{tabular}

Source: Ministry of Agriculture 2009.

Map (3) Reduction of farmland before urban expansion for up to one year. 1015.

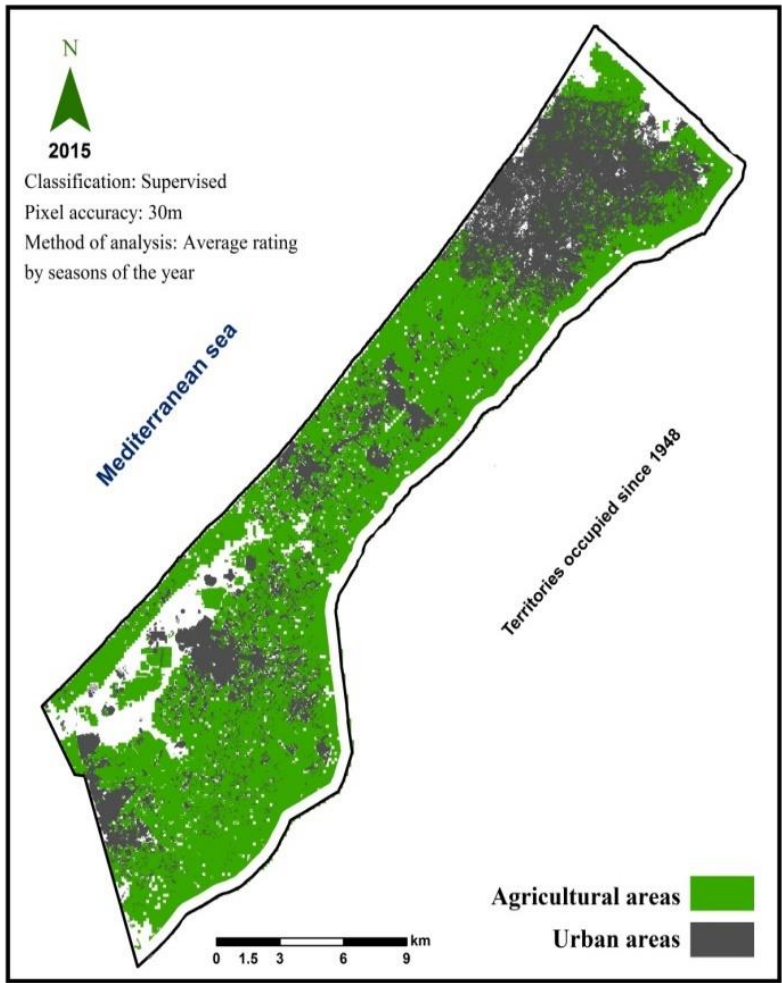

Source: Analysis of the researchers based on the geological data of the US Geological Survey.

\section{Israeli violations against the Palestinian farmers after 2012 Israeli military offensive on Gaza}

According to a report (10) by Al-Mezan Centre for Human Rights, the Israeli violations and restrictions against the Palestinian farmers have continued after the alleged ceasefire in October, 2012 in Egypt, particularly violations against the farmers and residents living near the border areas with Israel (see map 3).

The report describes the Israeli violations over the period from 22/11/2012 until 21/1/2013, including the civilian casualties caused by the Israeli forces near the border area.
Israeli occupation forces fired at Palestinian civilians 52 times in the border area, carried out 5 incursions, arrested 9 people including 5 children, killed 4 Palestinians, and wounded 74 people including 10 children. Furthermore, since the beginning of 2013 until 21/01/2013, 16 attacks were lunched on the border zone, killing 2 people and injuring 6 , including 2 children.

This brings the total number of attacks on the border areas in the Gaza Strip since the announcement of the occupation forces its intention to impose a no-man zone, i.e. a restricted area, late 2009 to reach 577 attack, killing 84 Palestinians, including 16 children and one female, and the wounding of 490 Palestinians, including 105 children and 19 women.

A report by United Nations Office for the Coordination of Humanitarian Affairs (OCHA) provided statistics that indicated that the Israeli occupation forces demolished $100 \%$ of agricultural lands and homes within a range of 500 meters along the border, and $75 \%$ within a range of 1000 meters. All Palestinian and international institutions and special United Nations agencies agree with the fact that the Israeli occupation forces ban Palestinians from access to a distance up to 1500 meters contrary to what Israeli forces claims that they would shoot anyone approaching the borders up to 300 meters. The report confirms that these Israeli violations increase the unemployment and poverty rates in the Palestinian society and affect negatively the vital resources of food and water on which people's lives, especially those living near the border areas which are generally agricultural lands considered to be the most fertile in the Gaza Strip (see picture 1).

Picture 1The Palestinian areas near the ceasefire line

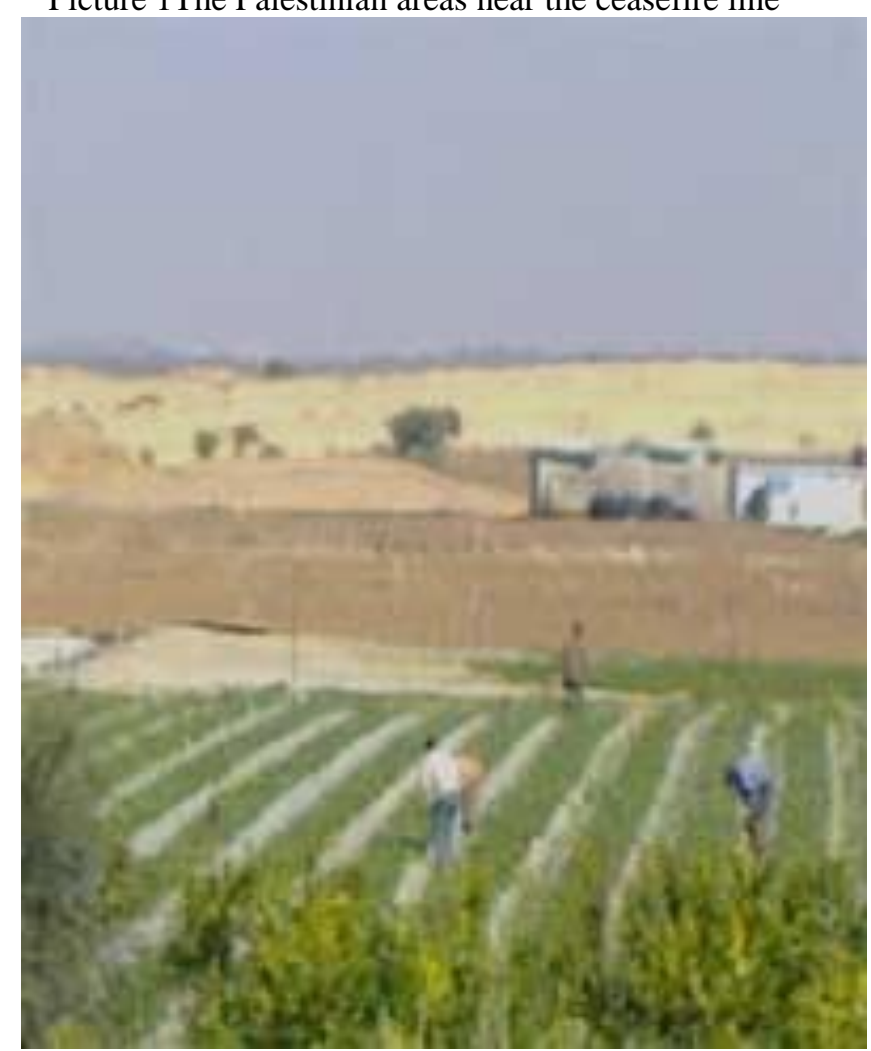

Source: Authors, Feb.2019 
The report also observes that hundreds of Palestinians were displaced from their lands near the Israeli borders and hundreds of houses and thousands of agricultural donums were demolished and razed to the ground under alleged security reasons (see picture 2). Finally, it warns of the ongoing confiscation by Israeli occupation forces of the right to life and security of the Palestinians, especially those living in the border areas in the east and the north.

The excessive use of force is one of the cornerstones of the Israeli strategy to perpetuate its military occupation, which is based on the principle of full readiness and possessing large force as powerful deterrent to protect Israel and prevent carrying out any military action against it. The use of force this is often called Israel's "punish and deter" strategy. Here you are some examples:

Picture 2A Palestinian farmer stands near his demolished land

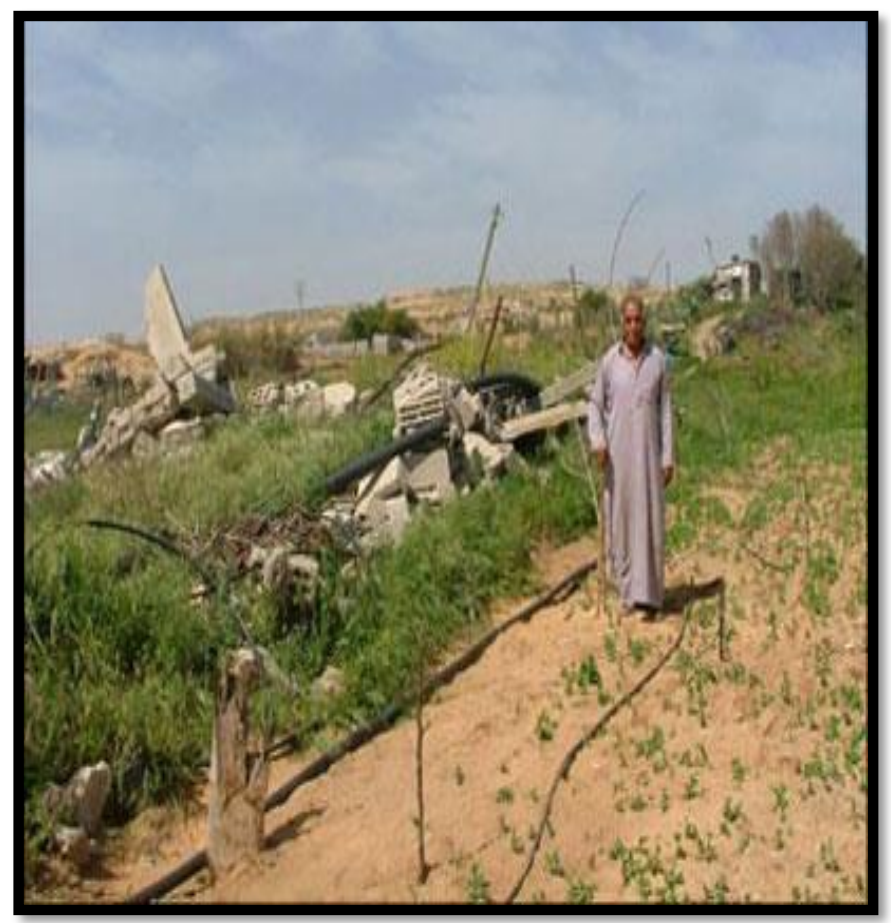

Source: Authors, Feb.2019

Third: Israeli Measures Used to Violate the Rights of the Palestinian Farmers in the Gaza Strip (11).

The use of force this is often called Israel's "punish and deter" strategy. Here you are some examples: The use of threat to impose conditions of temporary mutual adjustment with the aim of addressing its demands and conditions. Following the "limited reprisals" policy that embodies the practical implementation of the concept of military threat and moving from the dormancy stage to the actions stage. It also embodies the idea of having the adequate amount of force to take revenge on their opponents.

- Israel is constantly trying to permanently acquire the most highly sophisticated weapons and to achieve qualitative and quantitative superiority in military power.

- Raising the level of combat readiness through increasing the level of leadership quality, organizing the armed forces and transforming the economy in favor of the military effort.

- Finding the necessary pretexts for the use of force against the Palestinian farmers by deliberately misleading and falsifying facts and evidence in order to evade its responsibilities before the international community.

- Exaggerating the threats and losses caused by some incidents taking place in Israel or on the borders with the Gaza Strip, linking it to the security and safety of Israel. Israel, in that regard, often fabricates incidents so that they can easily create and influence the international public opinion to rationalize their crimes and aggressions against Palestinians.

- Israel is always trying to depict the Gaza Strip as the side which wages the war first, and Israel retaliates in self-defense against the Palestinian aggression. That is how Israel justified its wars on Gaza in 2008 a Recommendations:

- It is necessary to accomplish many procedures to remedy the damage to the agricultural sector and to repair and rehabilitate agricultural lands and facilities in order to keep the development of agriculture on the right track for the Palestinian development priorities. This requires the following:

- Reconsideration of the national policies to reflect the Palestinian needs, realities and priorities, especially since many donor countries, institutions and funds, on top of which is the World Bank, have begun to reconsider agriculture as a top priority.

- Modernizing and developing the agricultural policy and the operational program and adopting it as a mandatory framework and reference, particularly in light of the significant rise in the prices of Israeli products.

- Reconsideration of the ways the mechanisms of action are coordinated, and the allocation of aid, support and funding by private national institutions and donor countries to rehabilitate cultivate agricultural land and damaged facilities.

- The need to form groups to supporting the agricultural sector groups in order to attract more internal and external support.

- Paying due attention to livestock production by providing veterinary and health services and improving animal breeds in terms of productivity and disease resistance, and the provision of green and concentrated feed and pasture. In addition, farmers should be encouraged to invest in this area by facilitating the establishment of barns for livestock production.

- It is necessary to improve the transport, water and electricity infrastructure so as to improve agricultural production and its contribution to cover the local food needs as well as exporting surplus, especially in the peak productive seasons, for example, Olive oil. 


\section{REFERENCES}

[1] Adel Abd-Elsalam 1991. "The Natural features of the landscape in the State of Palestine. Institute for Arab researches and Studies (IARS), p. 142

[2] Salman Abu Sitta. 2009. Founder and president of the Palestine Land Society (PLS), London- Al-Hayya- 16794, p. 15, March.

[3] Khairia Qasmia 1991 "Settlements in the State of Palestine" Institute for Arab researches and Studies (IARS), p. 550.

[4] Atef Alawna, 1991. "The Impact of the Israeli Violations on the Palestinian Economy” Qadayia Magazine, No. 8, p. 120.

[5] Khairia Qasmia 1991 "Settlements in the State of Palestine" Institute for Arab Researches and Studies (IARS), p. 550

[6] Center for Human Rights.2005. The Fifth Report on the Israeli DSemolitions and Crimes in Gaza Strip, Palestinian, http://www.pchrgaza.org.

[7] Ministry of Agriculture Statistics, 2008.

[8] Ministry of Agriculture Statistics, 2008. -Ministry of Agriculture Statistics, 2009.

[9] Al-Mezan Centre for Human Rights 2010.

[10] Ibrahim Al-Abed, 1971. "An Introduction to the Israeli Strategies" Beirut.

[11] Field Study.

[12] Yousef Abu Mayla and Jouda Al-Torkomani, 1991. "Water Resources in the State of Palestine" (IARS), p. 214

[13] Palestinian Central Bureau of Statistics, 2009.

[14] Palestinian Central Bureau of statistics, 2009.

[15] Mohammed Ameer Qeeta 2009. "Israeli Settlements in West Bank and the Gaza Strip: Geopolitical study". Manara Bookshop, Gaza, Palestine.

[16] "The Ways of Integration and Disintegration between the Israeli and Palestinian Economy" Team of Arab experts of engineering and administration. P. 12, 1985.

[17] Mona Al-Jawhari 1989. "The Impact of Water and Land of the Growth of the Agricultural Economy in West Bank and the Gaza Strip". Ministry of Planning, Amman, p.43.

[18] Omran Abu Sbeeh. 1989. "The Impact of the Agricultural Sector on the Social Structure in West Bank" No. 76, p.49.

[19] Palestinian Central Bureau of Statistics, 2009.

[20] Palestinian Central Bureau of Statistics, 2009.

[21] "The Economic Features and the Structural Changes of Jerusalem2010" The Fourth Conference of Al-Quds, Al-Quds International Institution, Gaza, p. 84.

[22] Atef Alawna, 1991. "The Impact of the Israeli Violations on the Palestinian Economy" Qadayia Magazine, No. 8, p. 120.

[23] Fares Mohammed Abu Moammar and Kholoud Reyhan 2005. "The Role of the Palestinian Banks in Support of the Economic Sectors". Islamic University of Gaza, p. 25.

[24] Mohammed Ameera and Bassam Asfour 1978. "A Reflection of the Israeli Economic Violations on the economics of West Bank and the Gaza Strip" Amman, p. 8.

[25] Marwan Al-Qadoumi, Samed 1992. "A Reflection of the Israeli Economic Violations on Humanitarian and Legal Rights in the Occupied Territories in 1967." Economic Foundation No. 84, p.94.

[26] Arab Studies Society1980. "The Confiscation of Lands in the Occupied Territories" Jerusalem, p.42.

[27] Hisham Mohammed Radwan 2010. "The Economic Importance of the Agricultural Sector in Palestine" Gaza, p. 18.

[28] Hisham Mohammed Radwan 2010. "The Economic Importance of the Agricultural Sector in Palestine", Gaza, p. 18.

[29] Jad Ishaq and Nader Herman 2001. "The Palestinian Agricultural Sector and Prospects for Growth through the Scientific Research". The Applied Research Institute-Jerusalem.

[30] Hisham Mohammed Radwan, 2010. "The Economic Importance of the Agricultural Sector in Palestine" Gaza, p. 19.

[31] Hisham Mohammed Radwan 2010. "The Economic Importance of the Agricultural Sector in Palestine". Gaza, p. 22.

[32] Congregation for Palestinian Rights Centre2004 "A Report on the Israeli Assaults on the North of the Gaza Strip" 30 September, Retrieved from http://www.pal-cpr.org/reports/report65.htm.
[33] "Israel Theft of the Palestinian Water" by Palestinian News and Information Agency, 2004. Retrieved from http://www.pnic.gov.ps/arabic/resources/now3.html

[34] "Geographical Information Systems (GIS) Unit 2005." The Applied Research Institute-Jerusalem, 1 October Available at www.arij.org.

[35] The Applied Research Institute 2005 "The Palestinian Environment on World Environment Day" Jerusalem 5 June. Retrieved from http://www.arij.org/pub/pubarabic/Environment\%20Day\%205-062005/index.htm

[36] Human Rights Index in the Arab Countries1993. June 14. Retrieved from http://www.arabhumanrights.org.

\section{ACKNOWLEDGMENT}

The preferred spelling of the word "acknowledgment" in American English is without an "e" after the "g." Use the singular heading even if you have many acknowledgments. Avoid expressions such as "One of us (S.B.A.) would like to thank ... ." Instead, write "F. A. Author thanks ... ." Sponsor and financial support acknowledgments are placed in the unnumbered footnote on the first page.

[1] Motorola Semiconductor Data Manual, Motorola Semiconductor Products Inc., Phoenix, AZ, 1989.

\section{(Journal Online Sources style)}

[2] R. J. Vidmar. (August 1992). On the use of atmospheric plasmas as electromagnetic reflectors. IEEE Trans. Plasma Sci. [Online]. 21(3). pp. 876-880. Available: http://www.halcyon.com/pub/journals/21ps03-vidmar

(All authors should include biographies with photo at the end of regular papers.)

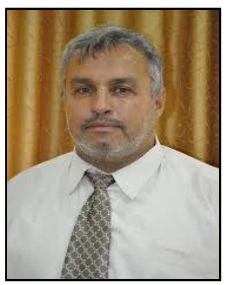

Dr. Fawzy Al - Jadbah

Associate Professor Master's economic geography of the research institute - Egypt Phd In the geography of services from the same institute Egypt Currently head of the Department of Geography and Information Systems Islamic University Gaza

Palestine.

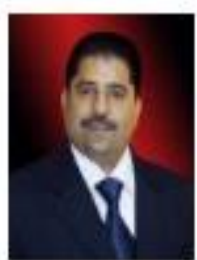

Dr. Raed Salha

Associate Professor, Department of Geography and Information Systems, Islamic University and Dean of the Faculty of Arts there $\mathrm{He}$ holds a Bc degree from King Saudi University of geography and he obtain his master's and PHd from research Institute-Egypt in geography and urban planning Dean, Faculty of Arts - The Islamic University of Gaza 